\title{
STABILITAS ANTOSIANIN DARI EKSTRAK BUAH MANGSI (Phyllanthus reticulatus poir).
}

\author{
Titik Irawati, Yushi Mardiana \\ Program Studi Agroteknologi, Fakultas Pertanian, Universitas Islam Kadiri \\ email : titiki160@gmail.com
}

\begin{abstract}
ABSTRAK
Tanaman mangsi (Phyllanthus reticulantus poir) merupakan famili euphorbiacea, buahnya berbentuk buni jika masak berwarna ungu kehitaman dan sedikit berasa asam. Pigmen berwarna ungu kehitaman tersebut diduga berasal dari senyawa antosianin. Antosianin adalah pigmen atau zat warna yang terkandung dalam buah, bunga, daun, batang dan akar suatu tanaman. Antosianin pada bagian-bagian tanaman dapat menghasilkan warna yang beragam, seperti orange, merah, magenta, ungu, dan biru, tergantung dari tingkat keasaman $(\mathrm{pH})$ pada lokasi dimana pigmen itu berada. Senyawa antosianin dapat dimanfaatkan sebagai pewarna alami, namun perlu ditinjau lebih dalam mengenai tingkat kestabilan dari pigmen antosianin tersebut. Penelitian ini bertujuan untuk mengkaji tingkat kestabilan antosianin terhadap suhu dan lama pemanasan. Penelitian ini menggunakan rancangan acak lengkap dengan faktor suhu pemanasan $(70,85,100)$ dan lama pemanasan $(30,60$, 90 Menit). Hasil penelitian menunjukkan bahwa pigmen antosianin buah mangsi cukup stabil suhu $70^{\circ} \mathrm{C}$ dan lama pemanasan 30 menit.
\end{abstract}

Kata kunci : buah mangsi, antosianin, stabilitas, pemanasan

\section{ABSTRACT}

Mangsi fruit (Phyllanthus reticulatus poir) belongs to euphorbiacea family. The fruit shapes buni, ripefruit colors blackish purple and tastes sour. The blackish purple pigmentis considered from anthocyanin compound. Anthocyanin is pigment or color substance containing in fruit, flower, leaf, stem and root. Anthocyanin in apart of plants can produce various colors, such as orange, red, magenta, purple, and blue, depends on $\mathrm{pH}$ level where the pigment located. Anthocyanin can be used as natural dyes, but needed to test deeply about stability level of anthocyanin it self. This research aims to determine the stability of anthocyanin level toward temperature and heating time. This research uses completely randomized design by some factors such as heating temperature (70, $\left.85,100{ }^{\circ} \mathrm{C}\right)$ and heating time (30,60, 90 minutes). The result of this research shows that anthocyanin pigment of mangsi fruit is stable enough in temperature $70^{\circ} \mathrm{C}$ and 30 minutes heating time.

Keywords: mangsi fruit, anthocyanin, stability, heating

\section{PENDAHULUAN}

Tanaman mangsi (Phyllanthus reticulantus poir), atau yang banyak dikenal dengan nama tampal besi merupakan tanaman yang banyak tumbuh di daerah kering dan terbuka. Tanaman ini tumbuh liar di lahan kosong atau di pekarangan rumah dan belum banyak dimanfaatkan. Buah mangsi yang masak berwarna ungu kebiruan, rasanya asam. Pada buah tersebut terdapat pigmen berwarna merah ungu yang larut dalam air. Pigmen dalam buah tersebut mengandung zat warna antosianin yang cukup tinggi. Antosianin merupakan salah satu pewarna alami yang merupakan zat berwarna merah, jingga, ungu, ataupun biru yang banyak terdapat pada bunga dan buah-buahan (Saati, 2010). Pigmen antosianin adalah golongan flavonoid merupakan pigmen yang paling luas dan penting karena banyak tersebar pada berbagai organ tanaman, terutama pada bunga, buah, daun (hampir 30\% terkandung dalam berat keringnya). Senyawa ini sudah banyak ditemukan di beberapa tanaman dan digunakan sebagai sumber pewarna alami seperti kelopak bunga rosela (Suzery, dkk. 2010); bunga rosella dan kembang sepatu (Siregar \& Nurlela, 2011); bunga mawar merah (Putri \& Fitri, 2015); kulit buah manggis (Farida \& Fitri, 2015); kulit buah naga (Ervaardinna, dkk. 2016).

Pada umunya aplikasi pewarna alami masih terkendala pada tingkat stabilitas dan kualitas warna. Kestabilan antosianin dipengaruhi oleh beberapa faktor antara lain $\mathrm{pH}$, suhu, cahaya, dan oksigen (Basuki dkk, 2005). Oleh karena perlu mengkaji lebih mendalam tentang potensi tanaman mangsi sebagai pewarna alami dari segi kestabilan 
warna. Tingkat kestabilan antosianin juga dipengaruhi oleh suhu dan laju degradasi antosianin. Semakin tinggi suhu larutan, maka warna senyawa antosianin akan semakin memudar. Degradasi termal menyebabkan perubahan warna antosianin dari merah keunguan menjadi coklat, dan semakin lama semakin memudar. Kenaikan $\mathrm{pH}$ dan suhu menyebabkan degradasi warna antosianin yang diekstrak dari buah buah cherri (Rein, 2005).

Berdasarkan latar belakang tersebut, perlu dilakukan penelitian tentang kajian stabilitas pigmen zat warna antosianin yang terdapat pada ekstrak buah mangsi (Phyllanthus reticulatus poir) terhadap suhu,dan lama pemanasan.

\section{METODE PENELITIAN}

Pada penelitian ini dilaksanakan pada bulan Junii 2018 dilaboratorium Teknologi Hasil Pertanian Universitas Brawijaya Malang dengan metode rancangan acak lengkap (RAL) terdiri 2 faktor yaitu suhu pemanasan $(75,85 \text { dan } 100)^{\circ} \mathrm{C}$ dan lama pemanasan $(30,60,90)$ menit, diulang sebanyak 3 kali. Peralatan yang digunakan antara lain : mortar, timbangan analitik, rotary vacuum evaporator, spektrofotometer UV-Vis, waterbath, corong kaca, beakerglass, erlenmeyer, tabung reaksi, labu ukur, aluminium foil, spatula, pipet ukur, kertas saring whatman 42. Bahan yang digunakan adalah buah mangsi, aquades, etanol $95 \%$, asam sitrat $10 \%$, buffer $\mathrm{pH} 1$ dan buffer $\mathrm{pH} 4.5$, asam hidroklorida $(\mathrm{HCl}) 37 \%$, petroleum eter.

\section{Preparasi Sampel}

Sampel buah mangsi yang akan diekstrak dilakukan sortasi dan dibersihkan dari kotoran yang masih menempel.

\section{Ekstraksi Metode Maserasi (Wrolstad \& Guisti , 2001) \\ Ekstraksi pewarna alami dari buah} mangsi dilakukan dengan menggunakan pelarut $\mathrm{HCl} 1.5 \%$ dalam etanol $95 \%$ sebanyak $100 \mathrm{~mL}$ dengan waktu maserasi 60 menit. Buah mangsi segar sebanyak 20gram dihaluskan dan dimaserasi dengan pelarut $100 \mathrm{~mL}$, kemudian disaring dengan kertas whatman 42. Filtrat bebas ampas yang diperoleh dimasukkan ke dalam corong pisah dan ditambahkan petroleum eter dan dilakukan pengocokan. Untuk menghilangkan pelarut yang ada dalam filtrat menggunakan rotary evaporator vaccum pada suhu $40^{\circ} \mathrm{C} \pm 1$. Hasil ekstraksi diukur nilai absorbansinya dengan menggunakan spektrofotometer UVVis pada panjang gelombang maksimal.

\section{Pengujian Stabilitas Terhadap Suhu dan lama Pemanasan (Jenie, dkk. 1997)}

Ekstrak buah mangsi yang diperoleh dilakukan pengujian untuk mengetahui stabilitas warna yang dihasilkan oleh antosianin buah mangsi terhadap pengaruh suhu $70^{\circ} \mathrm{C}, \quad 85^{\circ} \mathrm{C}$, dan $100^{\circ} \mathrm{C}$, lama pemanasan 30,60 dan 90 menit. $2 \mathrm{~mL}$ ekstrak diencerkan dengan aquades dalam labu ukur $100 \mathrm{~mL}$ hingga tanda batas. Hasil pengenceran diambil $10 \mathrm{~mL}$ dan dimasukkan dalam tiga tabung reaksi, masing-masing dengan volume yang sama yaitu $10 \mathrm{~mL}$ dan ditutup dengan alumunium foil. Proses pemanasan dilakukan dengan menggunakan waterbath pada suhu dan lama pemanasan yang bervariasi sesuai perlakuan. Volume larutan setelah pemanasan diusahakan sama dengan volume semula dengan cara menambahkan air suling panas kedalamnya. Selanjutnya dilakukan pengukuran nilai absorbansi pada panjang gelombang 200-700 $\mathrm{nm}$ dengan menggunakan spektrofotometer UV-Vis.

\section{HASIL DAN PEMBAHASAN}

Metode maserasi bertujuan untuk mengambil zat atau senyawa aktif yang terdapat pada suatu bahan menggunakan pelarut tertentu. Wrolstad \& Guisti (2001) menjelaskan dalam mengekstrak zat warna diperlukan metode yang sesuai dengan sifat bahan (sumber pigmen), agar dihasilkan rendemen dan stabilitas pigmen yang tinggi. Maserasi dengan mempertimbangkan sifat senyawa (antosianin) yang relatif rentan dan mudah rusak terhadap panas.

Perbandingan jumlah sampel dan pelarut pada proses maserasi sampel ini adalah $1: 5$, yaitu $20 \mathrm{~g}$ sampel dalam $100 \mathrm{~mL}$ pelarut. Pengukuran absorbansi maksimum ekstrak buah mangsi pada panjang gelombang $535 \mathrm{~nm}$ dengan nilai absorbansi maksimum 0,92. Pada kondisi tersebut $\mathrm{pH}$ masih berada dikisaran $1 \leq$. dimana pigmen antosianin berada dalam bentuk kation flavilium $\left(\mathrm{AH}^{+}\right)$terbanyak dan cenderung berwarna merah, sehingga intensitas warna meningkat dan nilai absorbansi tinggi (Bawoska, et.al 2003).

\section{Stabilitas Warna Antosianin Terhadap Pengaruh Suhu dan Lama Pemanasan Stabilitas warna pigmen akan menunjukkan kestabilan dari senyawa antosianin. Suhu memiliki peranan dan}


pengaruh yang sangat penting terhadap kestabilan antosianin. Tidak ada interaksi antara suhu dan lama pemanasan namun pada faktor tunggal terdapat perbedaan yang nyata (Tabel 1 ).

Tabel 1. Nilai absorbansi pengaruh suhu dan lama pemanasan

\begin{tabular}{c|c}
\hline Suhu Pemanasan $\left({ }^{\circ} \mathrm{C}\right)$ & Nilai Absorbansi \\
\hline 70 & $0,49 \mathrm{~b}$ \\
85 & $0,33 \mathrm{a}$ \\
100 & $0,28 \mathrm{a}$ \\
\hline BNT $(\alpha=0,05)$ & 0,06 \\
\hline Lama Pemanasan & Nilai Absorbansi \\
(menit) & \\
\hline 30 & $0,47 \mathrm{c}$ \\
60 & $0,37 \mathrm{~b}$ \\
90 & $0,27 \mathrm{a}$ \\
\hline
\end{tabular}

Keterangan : angka rerata yang diikuti dengan huruf yang sama pada kolom yang sama tidak berbeda nyata pada uji BNT $((\alpha=0,05)$.

Hasil dari uji BNT 5\% menunjukkan bahwa nilai absorbansi tertinggi diperoleh pada suhu $70^{\circ} \mathrm{C}$ dan lama pemanasan 30 menit. Semakin tinggi suhu dan lama pemanasan maka nilai absorbansi antosianin semakin rendah, sehingga stabilitas warnanya juga menurun. Secara visual pemanasan menyebabkan warna ekstrak zat warna buah mangsi memucat dan tidak stabil. Markakis (1992) melaporkan bahwa menurunnya nilai absorbansi ekstrak zat warna pada suhu tinggi disebabkan karena telah terjadi dekomposisi antosianin dari bentuk aglikon menjadi kalkon (tidak berwarna). Didukung Hendry \& Houghton (1996), suhu penyimpanan maupun suhu proses pengolahan mempengaruhi degradasi antosianin.

Hayati, dkk. (2012) menyatakan bahwa, suhu yang tinggi, dapat menyebabkan hidrolisis ikatan glikosidik pada antosianin dari ekstrak kelopak bunga rosella. Didukung oleh Oancea, et. al. (2012), yang menyatakan bahwa degradasi termal pada antosianin, dapat melepaskan gugus glikosil dan membentuk senyawa aglikon yang tidak berwarna.

\section{KESIMPULAN}

Dalam penelitian ini dapat ditarik kesimpulan bahwa kestabilan pigmen antosianin pada ekstrak buah mangsi (Phyllanthus reticulatus poir) cukup stabil pada suhu $70^{\circ} \mathrm{C}$ dengan nilai absorbansi $(0,49)$, lama pemanasan 30 menit dengan nilai absorbansi $(0,47)$.

\section{SARAN}

Diperlukan penelitian lebih lanjut tentang stabilitas pigmen antosianin buah mangsi (Phyllanthus reticulatus poir) pada $\mathrm{pH}$, suhu penyimpanan dan pengaruh cahaya.

\section{DAFTAR PUSTAKA}

Basuki, N., Harijono, Kuswanto, \&Damanhuri.2005. Studi Pewarisan Antosianin pada Ubi Jalar. Agravita27 (1): 63 - 68. ISSN: 0126 - 0537.

Bakowska, A., A.Z. Kucharska, dan J. Oszmianski. 2003. The Effects of Heating, UV Irradiation, and Storage on Stability of the AnthocyaninPolyphenol Copigment Complex. Journal of Food Chemistry. 81 (3) : 349-355.

Evaardinna; Ian Yuliati; Masturi . 2016. Ekstraksi Kulit Buah Naga (Dragon Fruit) Sebagai Zat Pewarna Alami Pada Kain Batik. Prosiding Pertemuan IImiah XXX HFI Jateng \& DIY, Salatiga 28 Mei 2016

Farida, R., Fitri, C. N. 2015. Ekstraksi Antosianin Limbah Kulit Manggis Metode Microwave Assisted Extraction (Lama Ekstraksi dan Rasio Bahan: Pelarut). Jurnal Pangan dan Agroindustri Vol. 3 No 2 p.362-373, April 2015

Hayati, S., Erawati Emi., Sari Risky, 2012. Pemanfaatan Limbah Daun Mangga Sebagai Pewarna Alami pada Kain Katun dan Sutra. Fakultas Teknik Kimia. Universitas Muhamadiyah Surakarta.

Hendry, G. A. F. and Houghton, J. D., 1996, Natural Food Colorant, 2nd Edition, Blackie Academic and Professional, London.

Jenie, B. S. L., K.D. Mitrajanty., S, Fardiaz. 1997. Produksi Konsentrat Pigmen Angkak dari Monascus Purpureus serta Kestabilannya selama Penyimpanan. Buletin. Teknol dan Industri Pangan, VIII (2): 39-46.

Markakis, P. 1992. Anthocyanins of Food Additive dalam Markakis, P (ed). Anthocyanins as Food Colors. Academic Press New York 263 pp.

Oancea, S. M. Stoia., D. Camon. (2012). Effects of Extraction Conditions on Bioactive Anthocyanin Content of Vaccinium corymbosum in the Perspective of Food Applications. Procedia Engineering 42 (2012) : 489 495.

Putri, A.R.W., Fitri, C. N. 2015. Ekstraksi antosianin dari Bunag Mawar Merah (Rosa damascene Mill) Sortiran Metode Microwave Assisted Extraction. Jurnal 
Pangan dan Agroindustri Vol 3 No 2. P. 701-712

Rein, M., 2005, Copigmentation Reactions and Color Stability of Berry Anthocyanin, Academic Dissertation, Helsinki: University of Heslinki

Saati, E.A. 2010. Identifikasi dan Uji Kualitas Pigmen Kulit Buah Naga Merah (Hylocereus Costaricensis) Pada Beberapa Umur Simpan dengan Perbedaan Jenis Pelarut. Jurnal GAMMA, Volume 6 (1). 25-34.

Siregar, I. D. Y dan Nurlela. 2011. Ekstraksi Dan Uji Stabilitas Zat Warna Alami Dari Bunga Kembang Sepatu (Hibiscus Rosa-Sinensis L) Dan Bunga Rosela
(Hibiscus Sabdariffa L) . Jurnal. Valensi Vol. 2 No. 3, Nop 2011 (459-467) ISSN : 1978 - 8193459.

Suzery. M., Sri Lestari., Bambang Cahyono. 2010. Penentuan Total Antosianin dari Kelopak Bunga Rosela (Hibiscus sabdariffa $L$ ) dengan Metode Maserasi dan Sokshletasi. Jurnal sains \& Matematika. Vol 18 Nomor 1, ISSN 0854-0675.

Wrolstad, R. E. and Giusti, M. M., 2001, Characterization and Measurement of Anthocyanin by UV-Visible Spectroscopy: Current Protocols in Food Analytical Chemistry, John Wiley and Son, New York 